Article

\title{
Synthesis of Atmospherically Stable Zero-Valent Iron Nanoparticles (nZVI) for the Efficient Catalytic Treatment of High-Strength Domestic Wastewater
}

\author{
Afzal Ansari ${ }^{1, *(D)}$, Vasi Uddin Siddiqui ${ }^{1}\left(\mathbb{D}\right.$, Md. Khursheed Akram ${ }^{2}$, Weqar Ahmad Siddiqi 1,*(D), \\ Anish Khan ${ }^{3, *(\mathbb{D})}$, Abeer Nasser Al-Romaizan ${ }^{4}$, Mahmoud A. Hussein ${ }^{4,5}$ and Madhu Puttegowda 6
}

\section{check for}

updates

Citation: Ansari, A.; Siddiqui, V.U.;

Akram, M.K.; Siddiqi, W.A.; Khan, A.; Al-Romaizan, A.N.; Hussein, M.A.; Puttegowda, M. Synthesis of Atmospherically Stable Zero-Valent Iron Nanoparticles (nZVI) for the Efficient Catalytic Treatment of High-Strength Domestic Wastewater. Catalysts 2022, 12, 26. https:// doi.org/10.3390/catal12010026

Academic Editor: Luigi Rizzo

Received: 12 December 2021

Accepted: 23 December 2021

Published: 27 December 2021

Publisher's Note: MDPI stays neutral with regard to jurisdictional claims in published maps and institutional affiliations.

Copyright: (c) 2021 by the authors Licensee MDPI, Basel, Switzerland. This article is an open access article distributed under the terms and conditions of the Creative Commons Attribution (CC BY) license (https:// creativecommons.org/licenses/by/ $4.0 /)$
1 Department of Applied Sciences and Humanities, Faculty of Engineering and Technology, Jamia Millia Islamia, New Delhi 110025, India; vasi168968@st.jmi.ac.in

2 Applied Sciences and Humanities Section, University Polytechnic, Faculty of Engineering and Technology, Jamia Millia Islamia, New Delhi 110025, India; makram@jmi.ac.in

3 Center of Excellence for Advanced Materials Research, King Abdulaziz University, Jeddah 21589, Saudi Arabia

4 Chemistry Department, Faculty of Science, King Abdulaziz University, Jeddah 21589, Saudi Arabia; aalromaizan@Kau.edu.sa (A.N.A.-R.); mahussein74@yahoo.com (M.A.H.)

5 Chemistry Department, Faculty of Science, Assiut University, Assiut 71516, Egypt

6 Department of Mechanical Engineering, Malnad College of Engineering, Hassan, Visvesvaraya Technological University, Belagavi 590018, India; madhu.p.gowda15@gmail.com

* Correspondence: afzal168969@st.jmi.ac.in (A.A.); wsiddiqui@jmi.ac.in (W.A.S.); akrkhan@kau.edu.sa (A.K.)

\begin{abstract}
Here, we report the fabrication of nZVI by the wet chemical technique in the presence of ethanol using ferric iron and sodium borohydride as the reducing agents under ambient conditions. The obtained nZVI particles are mainly in a zero-valent oxidation state and do not undergo significant oxidation for several weeks. The structural and morphological parameters of nZVI were investigated by using UV, XRD, SEM, EDX, TEM, and DLS analysis. The optical nature, bandgap energy, and absorption edge were all revealed by the UV-visible spectrum. The phase development and crystallinity of nZVI particles were shown by the XRD pattern. The morphological investigation revealed that the nanoparticles were spherical with an average size of 34-110 $\mathrm{nm}$ by using ImageJ software, and the elemental analysis was analyzed using EDX. Furthermore, the catalytic treatment performance of domestic wastewater was evaluated in terms of $\mathrm{pH}, \mathrm{COD}$ (chemical oxygen demand) solubilization, total solids (TS), volatile solids (VS), phosphorous, and total nitrogen (TN) reduction under aerobic and anaerobic operating conditions. The effluent was subjected to a process evaluation with a different range (100-500 mg/L) of nZVI dosages. The COD solubilization and suspended solids reduction were significantly improved in the anaerobic condition in comparison to the aerobic condition. Furthermore, the effect of nZVI on phosphorous $\left(\mathrm{PO}_{4}{ }^{3-}\right)$ reduction was enhanced by the electrons of iron ions. The high concentration of nZVI dosing has a positive impact on COD solubilization and phosphorous removal regardless of the aeration condition with $400 \mathrm{mg} / \mathrm{L}$ of nZVI dosage.
\end{abstract}

Keywords: fabrication; zero-valent iron; wastewater; solubilization; treatment

\section{Introduction}

Currently, wastewater is one of the most serious concerns of the world, caused by industrial/domestic waste or human-made sources [1,2]. Pollutants are discharged into the water by the industry without any prior treatment, resulting in significant water pollution, environmental and human health risks [3,4]. Until now, the primary sources of water contamination have been industrial and residential waste, mining, oil spills, nuclear waste, and pesticides [5-8]. Domestic and municipal wastewater is generally $99 \%$ water and $1 \%$ suspended, colloidal, and dissolved particles, predominantly organic since it includes 
the most carbon compounds, such as human waste, paper, and vegetable matter, as well as pathogens that consume oxygen from water bodies. Furthermore, mixing industrial effluents with urban sewage pollutes water bodies and wastewater-irrigated land [9-11]. The industrial sector used a huge amount of water and chemicals, and it discharged a lot of inorganic and organic pollutants, acid, bases, heavy metal ions, and dyes, among other pollutants [12-14]. The wastewater from the textile sector is one of the most complicated and harmful industrial effluents. Since every industrial sector generates its mixture of contaminants in wastewater, the treatment of these contaminants must be properly planned for the unique type of technology $[11,15,16]$. The current practices of wastewater treatments are biological processes that are used for domestic wastewater because they efficiently solubilize the various type of organic and inorganic contaminants $[14,17,18]$. The treatment of domestic or industrial wastewater using conventional processes (biological and physicochemical) is complicated due to the presence of high concentrations of organics, toxic heavy metals, and pathogen microorganism contents in the effluents $[2,19,20]$. Therefore, it is necessary to develop new technologies focusing on wastewater solubilization, improve the rate-limiting hydrolysis and solids reduction.

Since the last several decades, nanotechnology has been one of the fastest-growing fields in the scientific world, promising a possible shift in approaches to industrial wastewater treatment [21]. The nZVI have recently entered the field of wastewater treatment and gained plentiful attention in the degradation of biosolids and remediation of refractory toxic pollutants due to the high intrinsic reactivity of their surface area $[22,23]$. The nZVI can be synthesized using a variety of methods, all of which are being studied for potential applications in wastewater treatment. The $\mathrm{nZVI}$ is a low-cost reductant $\left(\mathrm{E}^{0}=-0.447 \mathrm{~V}\right)$ that is widely used in contaminated-site treatment [24]. The most well-known advanced oxidation processes (AOPs) include Fenton's process, which is used to reduce a bio-refractory organic compound from wastewater [25-27]. Fenton's process is an oxidation mechanism based on the catalytic degradation of $\mathrm{H}_{2} \mathrm{O}_{2}$ that depends on the hydroxyl radicals $\left(\mathrm{OH}^{0}\right)$ in the acidic $\mathrm{pH}[28,29]$. The $\mathrm{OH}^{0}$ bind to wastewater flocs and cells which are easily degraded and releases EPS into the liquid phase. The nZVI powder $\left(\mathrm{Fe}^{0}\right)$ can also be used as a catalyst in Fenton's process [30]. The combined process of nZVI and $\mathrm{H}_{2} \mathrm{O}_{2}$ has been used for the dewaterability of wastewater due to their oxidization capacity. Several studies have reported on a cost-effective technique of solids reduction using iron $\left(\mathrm{Fe}^{0}\right)$ scrap that increased the rate of volatile solids reduction (48.27\%) [31]. The nZVI scarp was used to provide electron donors for the anaerobic digestion of wastewater and the degradation was significantly enhanced when the nZVI dose was increased [32,33]. When nZVI particles were used with hydrogen peroxide (combined process) at $\mathrm{pH} 2$, the dewaterability capacity of wastewater was improved [34].

In this work, the function and effect of nZVI particles on the degradation and removal efficiency of domestic wastewater contaminants were investigated. Furthermore, the treatment/removal efficacy of COD solubilization and biosolids with various nZVI dosages was examined under different experimental conditions. The process of solid degradation, degree of solubilization, and phosphorous removal were investigated using chemical analysis. In addition, the effects of nZVI in wastewater treatment were compared to the standard oxidation approach.

\section{Results and Discussion}

\subsection{Characterization Results of $n Z V I$}

The UV-Visible spectrum of the nZVI particle was depicted in Figure 1a. The activation of surface plasmon vibrations in the nZVI solution results in two absorption peaks at 216 and $264 \mathrm{~nm}$, which are identical to the UV-visible spectrum of metallic iron and indicate the fabrication of nZVI particles. The optical bandgap $\left(E_{g}\right)$ of the synthesized samples were determined using the Tauc plot, hv vs. $(\alpha h v)^{2}$, as indicated in Figure $1 \mathrm{~b}$ using the following Equation (1):

$$
(\alpha . h v)^{\frac{1}{n}}=\mathrm{k}\left(\mathrm{h} v-\mathrm{E}_{\mathrm{g}}\right)
$$


where $\mathrm{k}$ is a constant, $\mathrm{h} v$ is the photon energy, $\mathrm{E}_{\mathrm{g}}$ the bandgap energy and the absorption coefficient $(\alpha)$. The $\mathrm{n}$ factor equals $1 / 2$ or 2 for the indirect and the direct band gaps, respectively, depending on the nature of the electric transition. The absorption peaks obtained at 216 and $264 \mathrm{~nm}$ are assigned to a characteristic peak of monodispersed iron nanoparticles in zero valent states [31]. The bandgap energy of synthesized nZVI particles was calculated to be $3.9 \mathrm{eV}$. This value is slightly higher to bulk iron, i.e., $\mathrm{Eg}=1.5 \mathrm{eV}$ [35]. These results further confirmed the formation of nanosized nZVI particles.
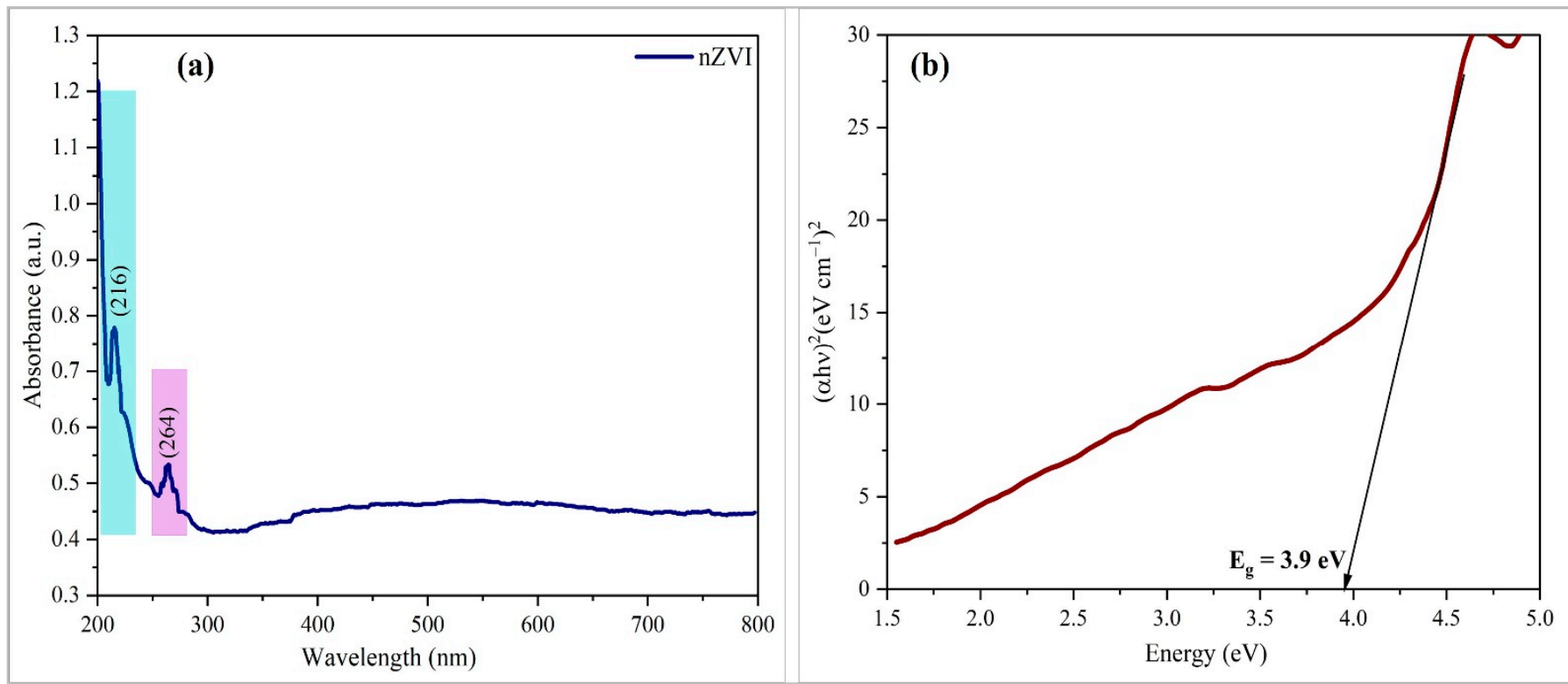

Figure 1. (a) UV-vis spectra of synthesized nZVI particles. (b) Tauc plot of synthesized nZVI particles.

XRD analysis was used to determine the crystallinity of freshly prepared nZVI particles, as shown in Figure 2. XRD analysis results can be used to calculate the average particle size of synthesized nanoparticles. The highest peak of the XRD spectrum indicates an intensity at $2 \theta=45.7^{\circ}$ demonstrated the (110) and (200) plane of nZVI and showed the crystalline phases of particles. The peaks of the diffraction patterns revealed a crystalline structure for the nZVI particles, and Miller indices were calculated using JCPDF cards 06-0696 [13]. The average crystalline size was found to be approximately $26.8 \mathrm{~nm}$ by using the Debay-Scherrer formula

$$
\mathrm{D}=0.9 \lambda / \beta \cos \theta
$$

where $\beta$ is the full-width half maxima of the peak, $\theta$ is the angle, $\lambda$ is the $X$-ray wavelength of XRD patterns.

SEM, TEM, and EDX analysis were used to investigate the typical morphology, size characteristics of nanoparticles, and elemental distribution analysis of each nZVI sample. Figure 3 shows the morphology, particle size, and elemental compositions of the synthesized nZVI, which has a dense porous surface and spherical, polydisperse structures with different processing adsorption capacity sizes. The result shows that some agglomerations of particles were found, which are represented by spherical shape and irregular size with different void spaces. Because of van der Waal's forces and magnetic attraction between $\mathrm{Fe}^{0}$ particles, a cluster of structures was observed at 20,000 $\times$ resolution in nZVI. Although the SEM micrographs provide direct visual evidence of particle size, due to the small number of iron particles examined, it is unable to estimate the size with high statistical certainty. The surface composition was investigated using an EDX coupled to an SEM instrument. Figure $3 \mathrm{~b}$ shows the elemental distribution of the nZVI particles as well as the percentage of the elements present. The averages of three experimental replications are shown in the bar graph. It can also provide qualitative and quantitative data on the elements that contribute 
to nanoparticles synthesis. The strongest peak in the EDX spectra of nZVI indicates the existence of $\mathrm{Fe}^{0}$ particles due to elemental iron absorption. Figure $3 \mathrm{~b}$ shows that Fe was the most abundant element on the surface of nZVI, accounting for 68.11 weight percent, followed by $\mathrm{O}$, which contributed 31.89 weight percent. The elemental mapping of EDX micrographs and the surface of nZVI particles, which is mostly constituent of iron (Fe), is shown in Figure 3c.

The nanoscale nZVI particles had a chain-like aggregated structure with particle diameters up to $110 \mathrm{~nm}$ by using ImageJ software, indicating that they were synthesized at the nanoscale. In the TEM micrographs, a single particle appears to be constituted of a dense core surrounded by a thin shell with much less contrast than the inner core. The nZVI nanoparticles have a chain-like structure and are covered on the surface by a passivation layer, as revealed by their natural magnetism and electrostatic interactions (Figure 4). The TEM image of the nZVI nanoparticles shows a helical shape with numerous pores that supports the adsorption or removal process. According to the graph, the iron content assisted is proportional to the volume of solution introduced into the method during the reduction process.

The hydrodynamic diameter of nZVI particles was precisely determined using particle size analysis (Figure 5). The particle sizes were measured to be $28.2 \mathrm{~nm}$, and the particle size distribution curve for $\mathrm{nZVI}$ showed an intensity of $12.7 \%$, which might indicate some agglomerations of nZVI particles in the solvent. However, chemically synthesized nanoparticles were agglomerated up to $2.3 \mu \mathrm{m}$ [36].

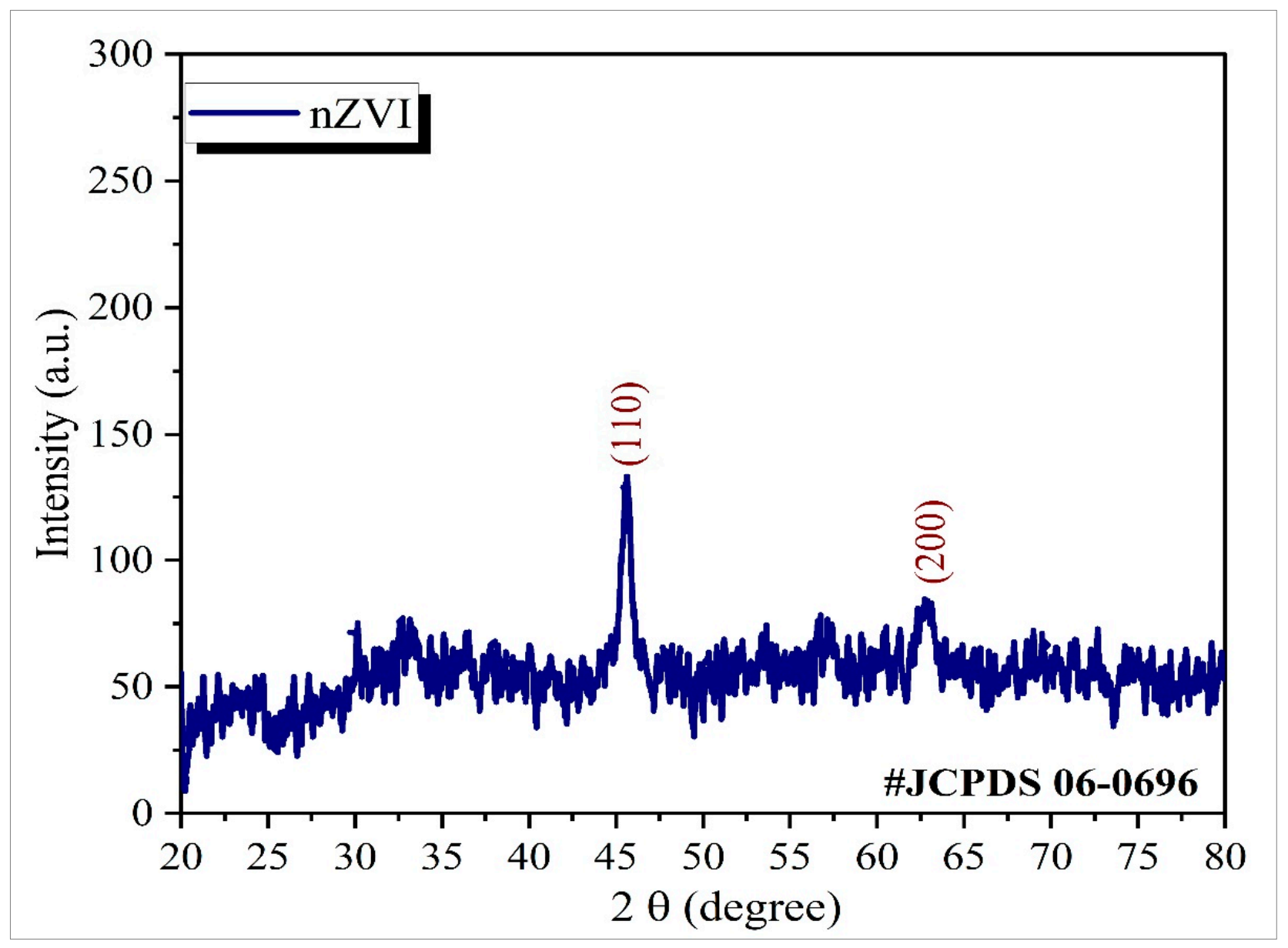

Figure 2. XRD spectra of synthesized nZVI particles. 

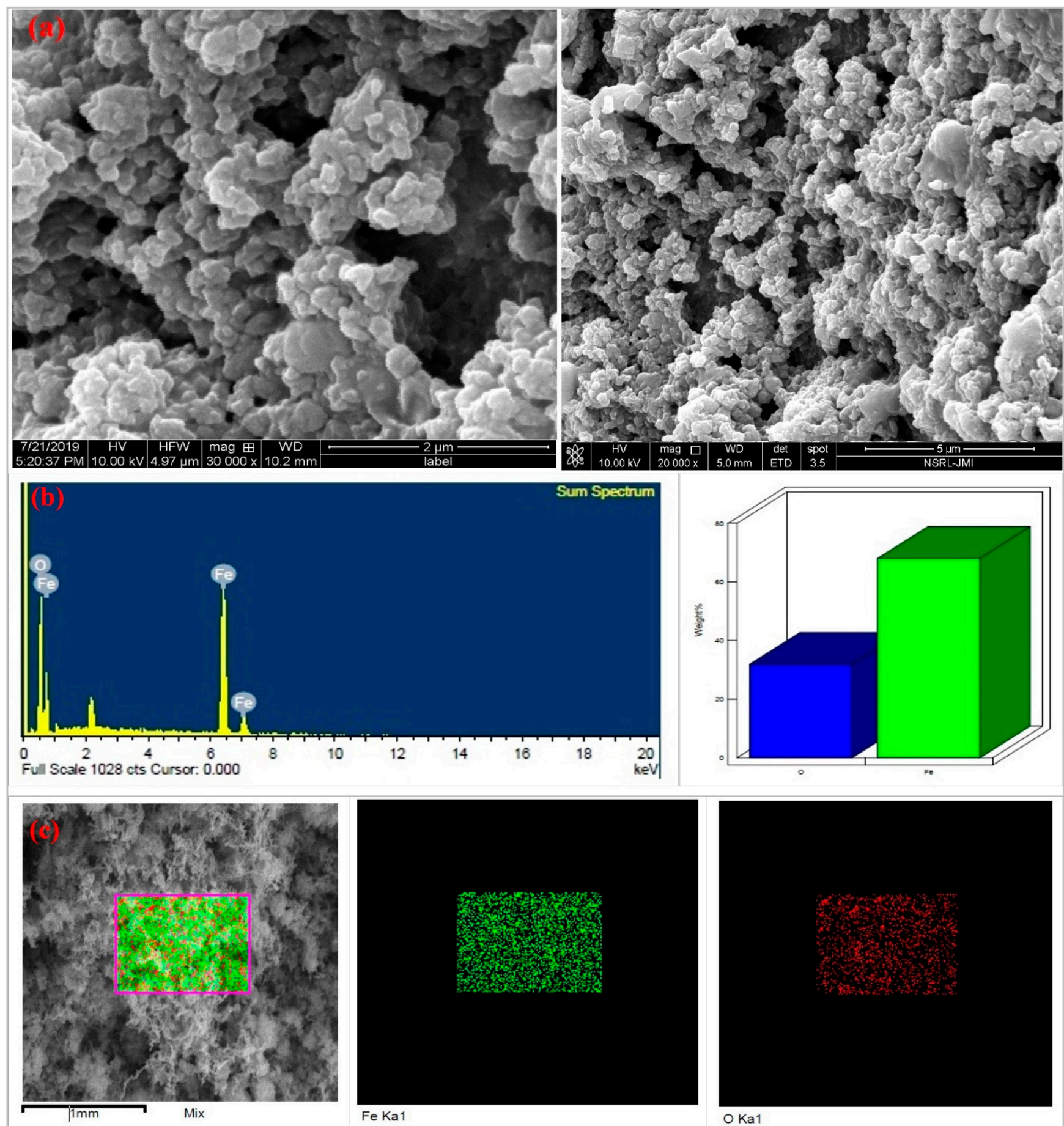

Figure 3. (a) SEM micrograph of nZVI at $2 \mu \mathrm{m}$ and $5 \mu \mathrm{m}$. (b) EDX spectrum of synthesized nZVI and (c) elemental mappings. 


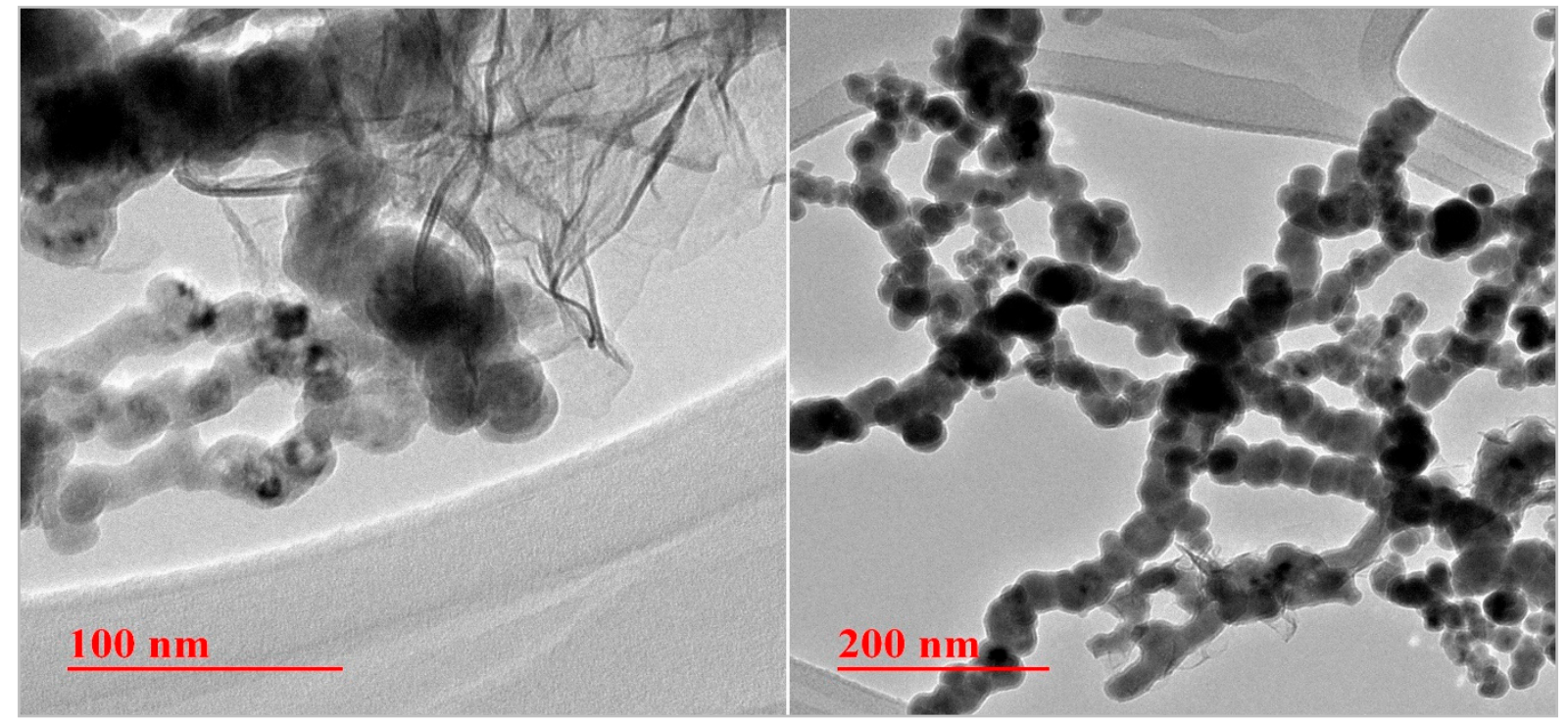

Figure 4. TEM micrographs of fresh nZVI at 100 and $200 \mathrm{~nm}$ scales.

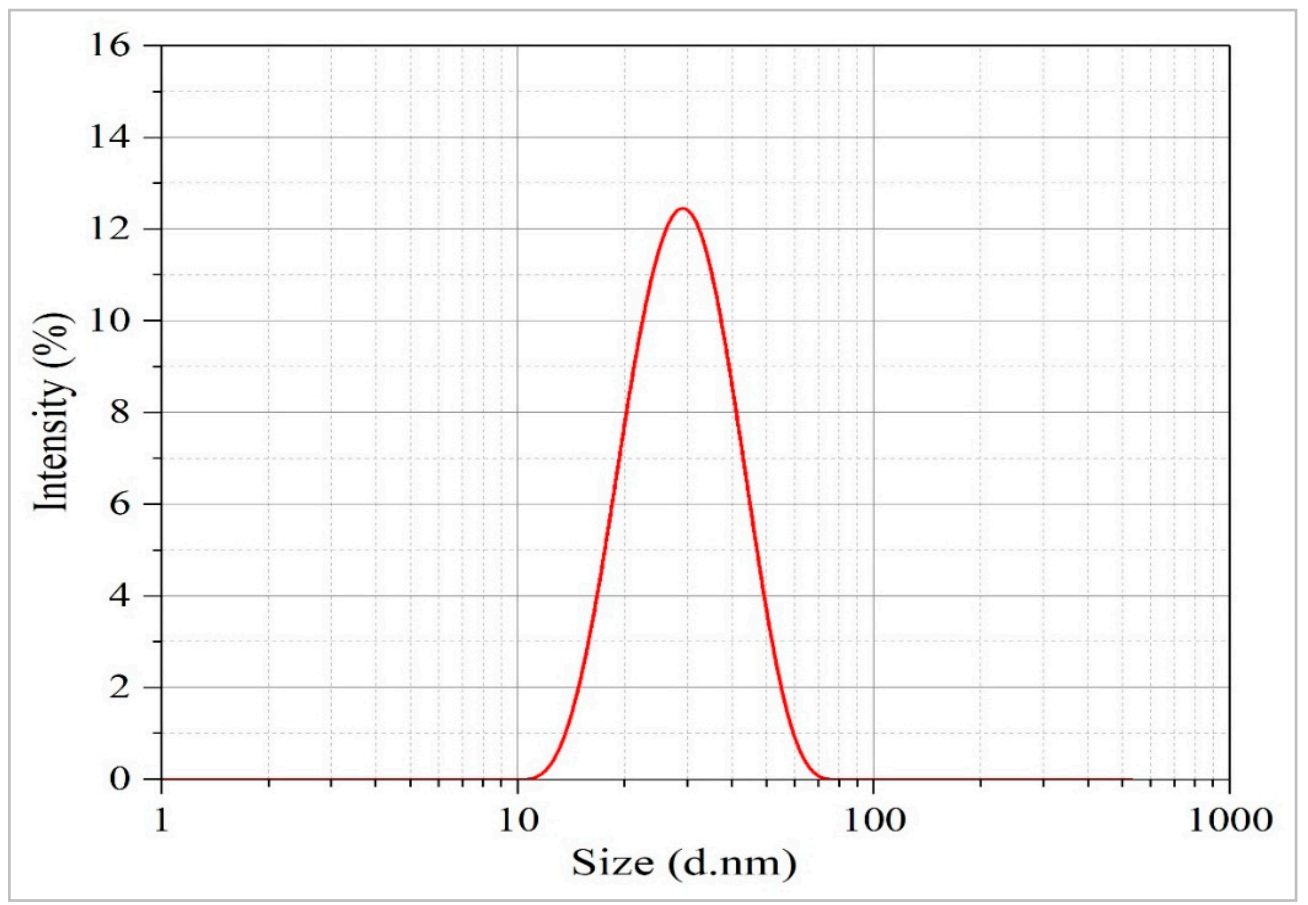

Figure 5. Particle size distribution (PSD) of synthesized nZVI particles.

\subsection{Effects of $n Z V I$ Particles on COD Solubilization}

The effect of different nZVI dosages on COD solubilization in aerobic and anaerobic conditions was investigated (Figure 6). The results show that significant COD solubilization was achieved within 60-120 min of treatment. The COD solubilization was reduced from $680 \mathrm{mg} / \mathrm{L}$ to $110,104,102,98,105 \mathrm{mg} / \mathrm{L}$ and 76, 72, 71, 71, $71 \mathrm{mg} / \mathrm{L}$ under aerobic and anaerobic conditions, respectively, when 100, 200, 300, 400, and $500 \mathrm{mg} / \mathrm{L} \mathrm{nZVI} \mathrm{dose} \mathrm{was}$ added. In both treatment conditions, COD solubilization increased linearly with increasing nZVI dosage concentration. After each $100 \mathrm{mg} / \mathrm{L} \mathrm{nZVI} \mathrm{dosages,} \mathrm{the} \mathrm{COD} \mathrm{concentration} \mathrm{in}$ both conditions decreased by 110 and $76 \mathrm{mg} / \mathrm{L}$, respectively. With increasing doses of nZVI, COD solubilization increased gradually to 98 and $71 \mathrm{mg} / \mathrm{L}$, respectively. A comparable improvement was observed with higher catalyst dosage $(200,300,400$, and $500 \mathrm{mg} / \mathrm{L})$ (Figure 6a). The concentration of nZVI was found to have a strong positive relationship 
with COD solubilization. Maximum COD solubilization at $400 \mathrm{mg} / \mathrm{L} \mathrm{nZVI} \mathrm{doses} \mathrm{was} 94$ and $71 \mathrm{mg} / \mathrm{L}$ in both treatment conditions. The COD solubilization increased gradually up to $120 \mathrm{~h}$, after which the solubilization was delayed and showed a minor increase. Reduced solubilization could be attributed to the formation of refractory compounds and their associated resistance to degradation After $120 \mathrm{~h}$ of exposure to $400 \mathrm{mg} / \mathrm{L} \mathrm{nZVI}$ nanoparticles, the degree of COD solubilization reached $92 \%$. After $120 \mathrm{~h}$ of treatment, the maximum reduction in COD concertation by nZVI catalyst was achieved under anaerobic conditions (Figure 6b). It was revealed that anaerobic conditions, when compared to aerobic conditions, can accelerate COD removal unless $300 \mathrm{mg} / \mathrm{L}$ of nZVI is added. However, no major difference was observed in COD solubilization after $400 \mathrm{mg} / \mathrm{L}$ nZVI dosages in both aerobic and anaerobic conditions. As a result, the optimal dose of nZVI was determined to be $400 \mathrm{mg} / \mathrm{L}$. Regardless of the nanoparticles or concentration doses, the equilibrium value was achieved after $80-100 \mathrm{~h}$ of exposure in the presence of oxygen. The hydroxyl radical has the potential to degrade complex floc structures, releasing intracellular organic matter into the soluble phase of the wastewater and increasing COD solubilization [37-39]. This could be due to the highly reactive and non-selective $\mathrm{OH}^{0}$ radical produced during the oxidation of the carbohydrate, protein, and other organic compounds released by the flocs $[18,40,41]$. The results of the current study were comparable to another finding in terms of COD solubilization. Martins et al. and Zhou et al. achieved COD solubilization ranging from 31.4 to $50.7 \%$ at $\mathrm{pH} 2$ and nZVI doses ranging from 500 to $750 \mathrm{mg} / \mathrm{L}$ [42,43] This could be attributed to the complete mineralization of the organic matters as a result of a high dose of nZVI and $\mathrm{H}_{2} \mathrm{O}_{2}$. However, in comparison to the current study, the result of Sahinkaya et al. was found to be $22.2 \%$ at $\mathrm{pH} 3$ and nZVI dosages of $4 \mathrm{~g} / \mathrm{kg}$ TS [44]. Finally, it can be stated that COD solubilization can be improved by using nZVI with anaerobic conditions. The decrease in COD concentration indicates floc disruption, cell lysis, and the release of intracellular organic materials into the liquid phase.
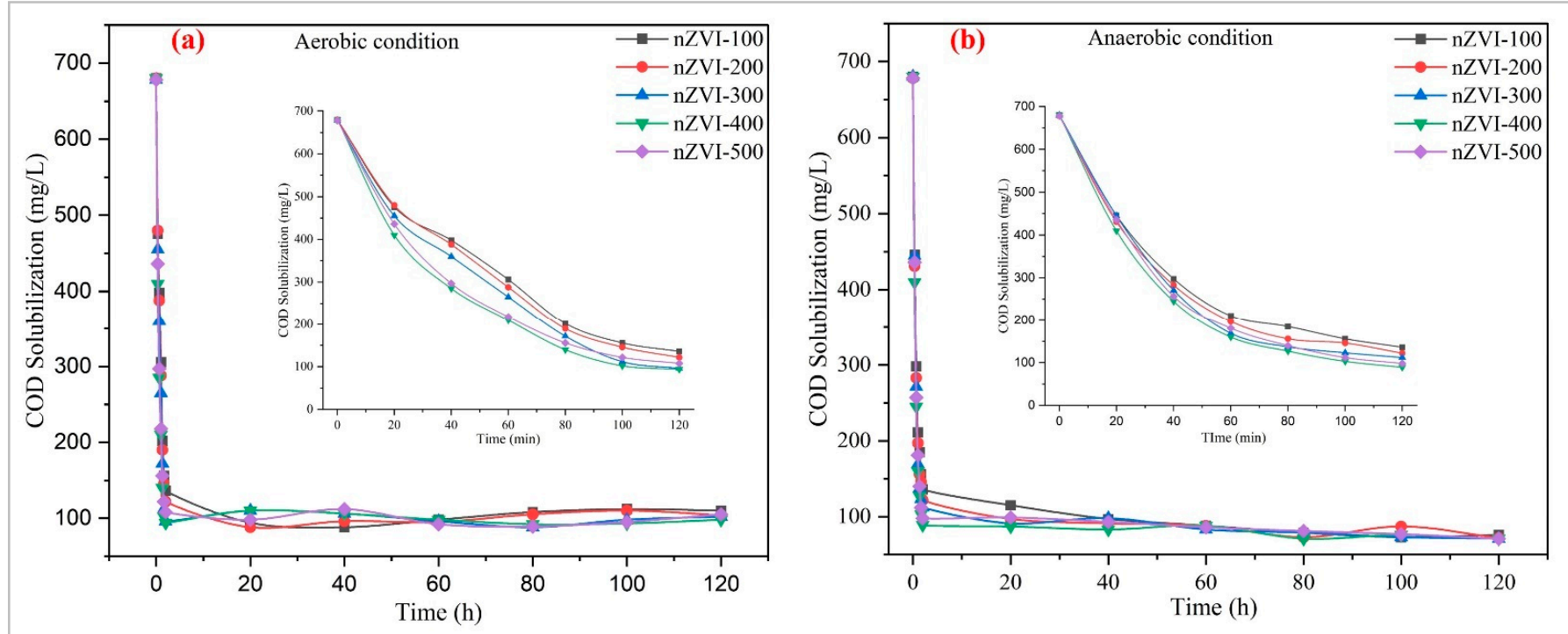

Figure 6. COD solubilization at different dosage of nZVI and conditions: (a) aerobic; the first $120 \mathrm{~min}$ of the aerobic treatment (inset) (b) anaerobic; the first $120 \mathrm{~min}$ of the anaerobic treatment (inset).

\subsection{Effects of nZVI Particles on Solid Reduction}

The suspended solids reduction is an important indicator for wastewater treatment. The effect of different nZVI dosages on suspended solid reduction was depicted in Figure 7. The concentration of suspended solids in the wastewater decreased with increasing catalyst dosage and treatment time. The initial suspended solid concentration was $332 \mathrm{mg} / \mathrm{L}$, which rapidly decreased to $20 \mathrm{mg} / \mathrm{L}$ after the first $60-120 \mathrm{~min}$ of aerobic and anaerobic treatment, with SS reductions of 86 and 92\%, respectively. In $120 \mathrm{~min}$, a maximum suspended solid re- 
duction was observed with $400 \mathrm{mg} / \mathrm{L}$ of nZVI catalyst dosage in both treatment conditions. When compared to $300 \mathrm{mg} / \mathrm{L}$ of nZVI in aerobic conditions, the nZVI dosage of $500 \mathrm{mg} / \mathrm{L}$ showed a slight increase (almost sustained) in suspended solid reduction after $120 \mathrm{~h}$ of treatment (Figure 7a). In anaerobic conditions, $300 \mathrm{mg} / \mathrm{L}$ of nZVI dosage showed a significant reduction in solids after $120 \mathrm{~h}$ of treatment. The degree of suspended solid reduction was in the range of $48-92 \%$ for both treatment conditions. The maximum reduction in solids was obtained within 120 min of anaerobic treatment conditions (Figure $7 \mathrm{~b}$ ). Furthermore, in both treatment conditions, treatment times exceeding $80 \mathrm{~h}$ did not show a significant increase in suspended solid reduction. The reduction in suspended solids reveals wastewater stability and is used to assess process efficiency and stabilize wastewater. The breakdown of solid flocs and the disruption of EPS has increased by suspended solids reduction into the liquid medium while simultaneously reducing total and volatile solids. The VS/TS ratio of the sludge decreased from $71 \%$ to $26 \%$ after treatment with aerobic and anaerobic conditions, indicating mineral solubilization. The air acted over the flocs during the aerobic treatment, loosening them through EPS disruption. Further application of air destroyed the cell wall, allowing the intracellular organic material to be released [3,14,29]. The addition of nZVI particle scrap to wastewater resulted in a $48.27 \%$ increase in the rate of volatile solids reduction. During the anaerobic oxidation phase of wastewater treatment using nZVI particles, the ratio of the suspended solid decreased linearly, indicating an accumulation of inorganic components in the wastewater [45]. These findings are consistent with previous studies on other conventional Fenton processes [18,25,46]. According to Kim et al. and Pham et al. the Fenton process improved the dewaterability of wastewater by $49 \%$ to $74 \%$ solid reduction efficiency $[47,48]$. However, the anaerobic condition approach resulted in a significant reduction in suspended solids containing nZVI particles. This might be due to the accumulation of more refractory compounds in the wastewater.
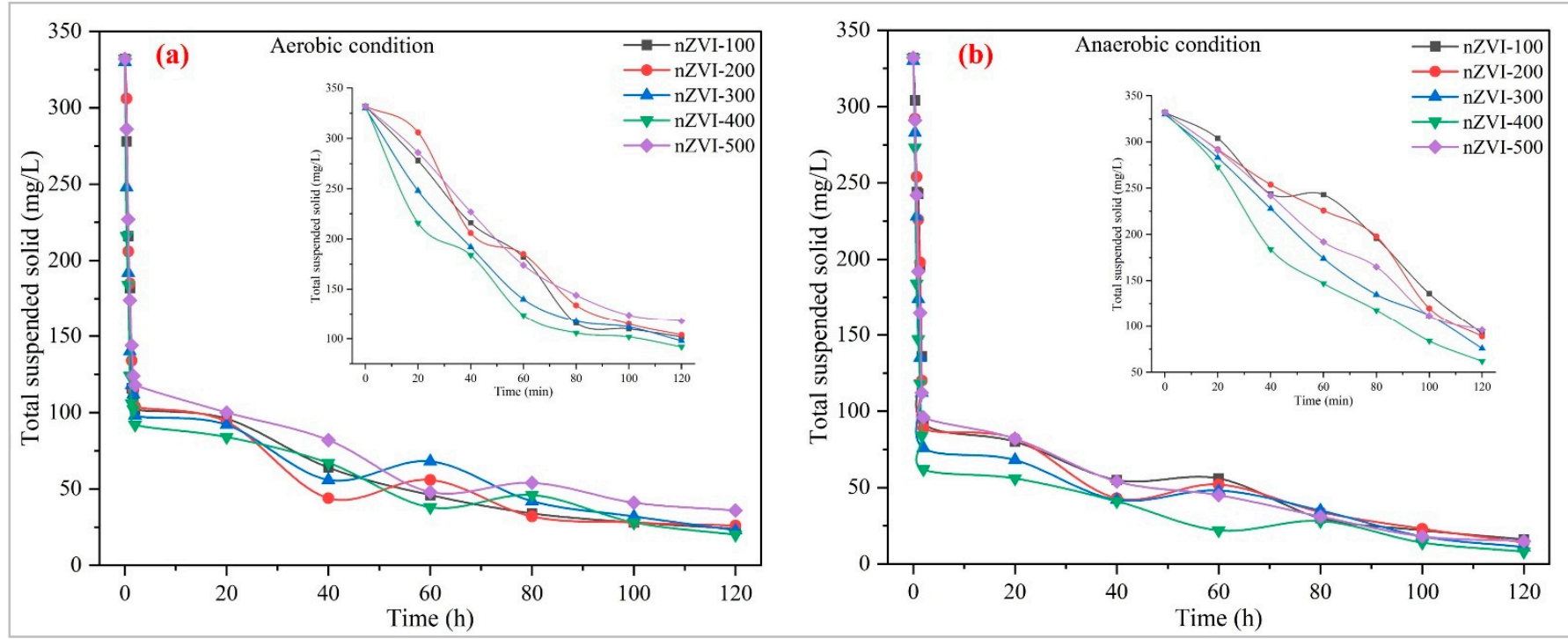

Figure 7. TSS reduction at a different dosage of nZVI and conditions: (a) aerobic; the first 120 min of the aerobic treatment (inset) (b) anaerobic; the first $120 \mathrm{~min}$ of the anaerobic treatment (inset).

\subsection{Effects of nZVI Particles on Phosphorous Removal}

The phosphorus concentration in the wastewater was chemically controlled through adsorption with nZVI particles. Although the phosphorus concentration in the batch experiment only decreased from 13.86 to $0.42 \mathrm{mg} / \mathrm{L}$ in the absence of air, the reduction in phosphorus in the aerobic condition was observed to be lower than in the anaerobic condition, as shown in Figure 8. Furthermore, the increasing dose of nZVI particles increased the phosphorus removal efficiency under anaerobic conditions, with phosphorus 
concentrations decreasing from $13.86 \mathrm{mg} / \mathrm{L}$ to $1.12,0.86,0.64,0.42$, and $1.20 \mathrm{mg} / \mathrm{L}$ when $100,200,300,400$, and $500 \mathrm{mg} / \mathrm{L}$ nZVI particles were added, respectively.

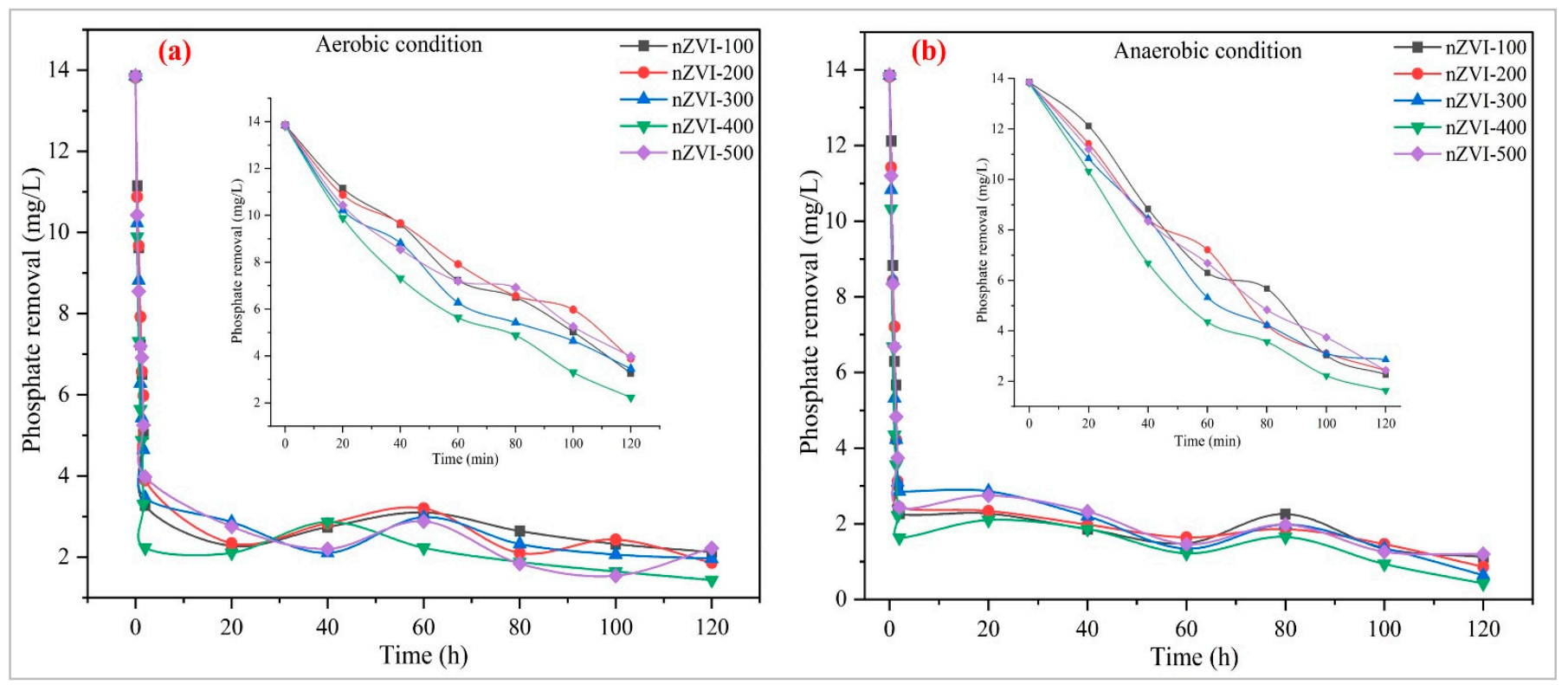

Figure 8. Phosphate removal at a different dosage of nZVI and conditions: (a) aerobic; the first $120 \mathrm{~min}$ of the aerobic treatment (inset) (b) anaerobic; the first $120 \mathrm{~min}$ of the anaerobic treatment (inset).

However, the phosphorus content of wastewater samples was reduced to $1.12 \mathrm{mg} / \mathrm{L}$ after exposure to $100 \mathrm{mg} / \mathrm{L}$ of nZVI dosage. The results showed that using nZVI particles improved the phosphorus removal rate, and as the nZVI dose was increased, the phosphorus removal equilibration capacity gradually increased. Figure 8 a shows that phosphorus adsorption on the nZVI surface is initially rapid, with more than $80 \%$ phosphorus absorption occurring within the first $120 \mathrm{~min}$. Thereafter, phosphorus absorption gradually increased in both treatment conditions. The adsorption equilibrium was approached after 120 min under aerobic conditions and the phosphorus concentration remained almost sustained. While removal equilibrium under anaerobic conditions showed significant removal of the phosphorus after $120 \mathrm{~min}$ of treatment. The removal efficiency of phosphorus improved significantly when only $100 \mathrm{mg} / \mathrm{L}$ of nZVI was used, due to the complete dissolution of nZVI particles, which generated iron ions components. However, when nZVI dosages are above $400 \mathrm{mg} / \mathrm{L}$, the rate of phosphorus removal appears to be slower. After 120 min, significant phosphorus removal to supports all nZVI dosages under both treatment conditions. However, a further increasing the nZVI dose to $500 \mathrm{mg} / \mathrm{L}$ did not improve phosphorus removal efficiency, whereas $400 \mathrm{mg} / \mathrm{L}$ nZVI particle dosages showed better phosphorus removal after $120 \mathrm{~min}$ and phosphorus concentrations were reduced to $0.42 \mathrm{mg} / \mathrm{L}$ under anaerobic conditions (Figure $8 \mathrm{~b}$ ). As a result, increasing the nZVI particle concentration as an adsorbent increased the surface area of the nZVI particles, which contains the iron ions electrons components, resulting in more vacant sites, which improved phosphorus adsorption $[49,50]$.

Based on the observed phenomena and the literature, the high reactivity of nZVI nanoparticles can only be achieved in anaerobic conditions due to the interaction of the nZVI and oxygen. Iron ion components are associated with increased phosphorus adsorption rates from the wastewater [51,52]. Since nZVI particles have a larger surface area, they may have a larger active site on the surface of the nanoparticles, allowing phosphorus to be absorbed more easily. A schematic representation of the mechanism during the treatment process of domestic wastewater with nZVI particles is shown in Figure 9. Furthermore, the phosphorus concentration decreased as a result of the continuous release of $\mathrm{Fe}^{2+}$ and/or $\mathrm{Fe}^{3+}$, which has a significant impact on the coagulation/precipitation process. [22,40]. 


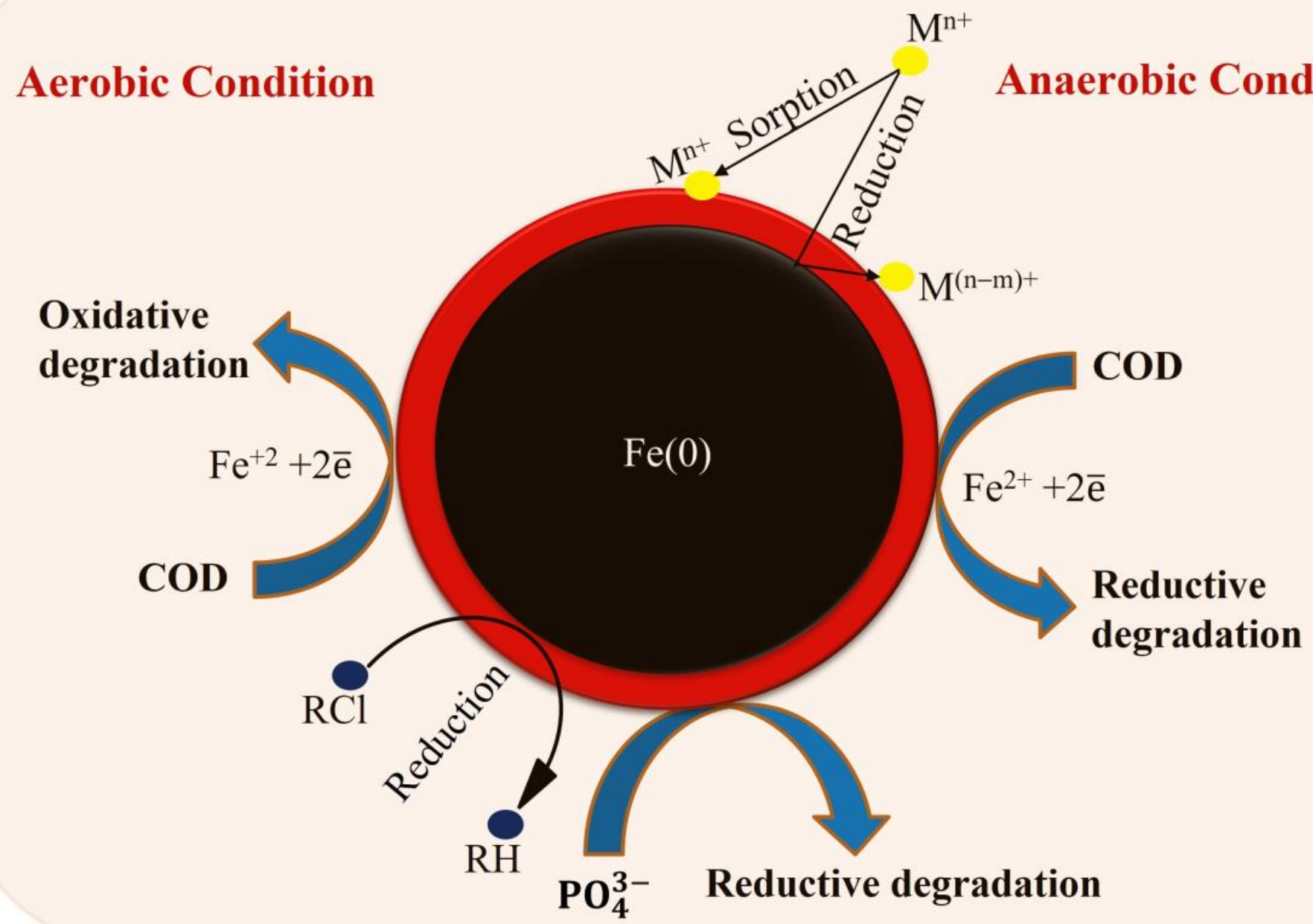

Figure 9. Schematic representation of the reaction during the treatment process of domestic wastewater with nZVI particles.

\subsection{Statistical Analysis}

\subsubsection{Correlation Studies}

Table 1 shows the Pearson correlation matrices for five variables. The correlation matrix result for aerobic treatment shows a positive correlation between COD and TSS $\left(\mathrm{r}^{2}=0.98\right)$ and VS $\left(\mathrm{r}^{2}=0.99\right)$. Likewise, COD negatively correlated with $\mathrm{PO}_{4}{ }^{3-}\left(\mathrm{r}^{2}=-0.98\right)$ and TN $\left(\mathrm{r}^{2}=-0.97\right)$ in aerobic treatment of condition. Similarly, the TSS shows a strong positive correlation with VS $\left(\mathrm{r}^{2}=0.98\right)$ and $\mathrm{PO}_{4}{ }^{3-}\left(\mathrm{r}^{2}=0.97\right)$ while $\mathrm{TN}$ shows a negative correlation with TSS $\left(\mathrm{r}^{2}=-0.94\right)$ and $\mathrm{PO}_{4}{ }^{3-}\left(\mathrm{r}^{2}=-0.99\right)$ in aerobic condition. The correlation matrices for the anaerobic treatment condition reveal that COD activity is positively correlated with TSS $\left(\mathrm{r}^{2}=0.97\right), \mathrm{PO}_{4}{ }^{3-}\left(\mathrm{r}^{2}=0.98\right)$ and $\mathrm{TN}\left(\mathrm{r}^{2}=0.96\right)$ but negatively correlated with VS $\left(\mathrm{r}^{2}=-0.86\right)$. Likewise, the activity of TSS and $\mathrm{PO}_{4}{ }^{3-}$ shows a positive correlation with VS $\left(r^{2}=0.99\right)$ and $\mathrm{TN}\left(\mathrm{r}^{2}=0.98\right)$ in anaerobic condition. 
Table 1. Correlation matrixes of the different parameters at aerobic and anaerobic treatment.

\begin{tabular}{cccccc}
\hline \multicolumn{5}{c}{ Aerobic Treatment } \\
\hline COD & TSS & VS & PO $_{4}{ }^{3-}$ & TN \\
\hline COD & 1 & & & & \\
TSS & 0.98 & 1 & 1 & & \\
VS & 0.99 & 0.98 & 0.99 & 1 & 1 \\
PO $_{4}{ }^{3-}$ & -0.98 & 0.97 & -0.95 & -0.99 & 1 \\
TN & -0.97 & -0.94 & & \\
\hline
\end{tabular}

Table 1. Cont.

\begin{tabular}{cccccc}
\hline \multicolumn{5}{c}{ Anaerobic Treatment } \\
\hline COD & TSS & VS & PO $_{4}{ }^{3-}$ & TN \\
\hline TSS & 1 & & & \\
VS & 0.97 & 1 & 1 & & \\
PO $_{4}{ }^{3-}$ & -0.86 & 0.99 & -0.91 & 1 & 1 \\
TN & 0.98 & -0.91 & 0.99 & 0.98 & 1 \\
\hline
\end{tabular}

(a) Strong correlation $\left(\mathrm{r}^{2}=1.0\right.$ to 0.5 or -1.0 to -0.5$)$ (b) Moderate correlation $\left(\mathrm{r}^{2}=0.3\right.$ to 0.5 or -0.5 to -0.3$)$ (c) Weak correlation $\left(\mathrm{r}^{2}=0.1\right.$ to 0.3 or -0.3 to -0.1$)(\mathrm{d})$ None or very weak $\left(\mathrm{r}^{2}=0.1\right.$ to -0.1$)$.

\subsubsection{Analysis of Variance (ANOVA) Test}

The ANOVA is a statistical analysis method that distributes the total variability present within a data set. Tables exhibit the ANOVA tests of the entire systematic factor (variables) of COD solubilization from aerobic and anaerobic treatment conditions. The two-way ANOVA test of COD of aerobic treatment turned to be highly significant with $p$-values $<0.05$ while in anaerobic treatment statistically nonsignificant with $p$-values $>0.05$ (Table 2). Similarly, the ANOVA test of TSS reduction in both treatment conditions (aerobic and anaerobic) is statistically significant with $p$-values $<0.05$ (Table 3). Likewise, the ANOVA test of phosphorous removal in aerobic treatment was found to be statistically significant; however, in anaerobic conditions, it was determined to be nonsignificant with $p$-values $>0.05$ (Table 4$)$.

Table 2. Analysis of variance (ANOVA) test of COD solubilization of aerobic and anaerobic treatment.

\begin{tabular}{ccccccc}
\hline \multicolumn{7}{c}{ Aerobic Treatment } \\
\hline $\begin{array}{c}\text { Source of } \\
\text { Variation }\end{array}$ & COD & $d f$ & MS & $\boldsymbol{F}$ & $\boldsymbol{p}$-Value & $\boldsymbol{F}$ Crit \\
\hline Rows & $1.09 \times 10^{9}$ & 5 & $2.18 \times 10^{8}$ & 21.04978 & 0.000003 & 2.901295 \\
Columns & $5.86 \times 10^{8}$ & 3 & $1.95 \times 10^{8}$ & 18.91021 & 0.000023 & 3.287382 \\
Error & $1.55 \times 10^{8}$ & 15 & $1.03 \times 10^{7}$ & & & \\
Total & $1.83 \times 10^{9}$ & 23 & & & & \\
\hline \multicolumn{7}{c}{ Anaerobic Treatment } \\
Rows & $2.15 \times 10^{9}$ & 5 & $4.3 \times 10^{8}$ & 277.7312 & $4.17 \times 10^{-6}$ & 5.050329 \\
Columns & $7.50 \times 10^{5}$ & 1 & $7.50 \times 10^{5}$ & 0.483871 & $0.51 \times 10^{-7}$ & 6.607891 \\
Error & $7.75 \times 10^{6}$ & 5 & $1.55 \times 10^{6}$ & & & \\
Total & $2.16 \times 10^{9}$ & 11 & & & & \\
\hline
\end{tabular}


Table 3. Analysis of variance (ANOVA) test of TSS reduction in aerobic and anaerobic treatment.

\begin{tabular}{ccccccc}
\hline \multicolumn{7}{c}{ Aerobic Treatment } \\
\hline $\begin{array}{c}\text { Source of } \\
\text { Variation }\end{array}$ & TSS & $d f$ & MS & $\boldsymbol{F}$ & $\boldsymbol{p}$-Value & $\boldsymbol{F}$ Crit \\
\hline Rows & 5.28 & 5 & 1.06 & 179.5706 & $7.9 \times 10^{-8}$ & 2.901295 \\
Columns & $2.46 \times 10^{-2}$ & 3 & $8.22 \times 10^{-3}$ & 1.396694 & $0.28 \times 10^{-6}$ & 3.287382 \\
Error & $8.82 \times 10^{-2}$ & 15 & $5.88 \times 10^{-3}$ & & & \\
Total & 5.39 & 23 & & & \\
\hline \multicolumn{7}{c}{ Anaerobic Treatment } \\
\hline Rows & $5.16 \times 10^{-1}$ & 5 & $1.03 \times 10^{-1}$ & 43.4757 & $1.8 \times 10^{-6}$ & 3.325835 \\
Columns & $1.78 \times 10^{-4}$ & 2 & $8.89 \times 10^{-5}$ & 0.037452 & 0.96338 & 4.102821 \\
Error & $2.37 \times 10^{-2}$ & 10 & $2.37 \times 10^{-3}$ & & & \\
Total & $5.40 \times 10^{-1}$ & 17 & & & & \\
\hline
\end{tabular}

Table 4. Analysis of variance (ANOVA) test of phosphorous removal of aerobic and anaerobic treatment.

\begin{tabular}{ccccccc}
\hline \multicolumn{7}{c}{ Aerobic Treatment } \\
\hline $\begin{array}{c}\text { Source of } \\
\text { Variation }\end{array}$ & $\mathbf{P O}_{4}{ }^{3-}$ & $d f$ & $\boldsymbol{M S}$ & $\boldsymbol{F}$ & $\boldsymbol{p}$-Value & $\boldsymbol{F}$ Crit \\
\hline Rows & 1.98 & 5 & $3.95 \times 10^{-1}$ & 247.5868 & $3.8 \times 10^{-10}$ & 3.325835 \\
Columns & $1.53 \times 10^{-2}$ & 2 & $7.63 \times 10^{-3}$ & 4.779241 & 0.03494 & 4.102821 \\
Error & $8.82 \times 10^{-2}$ & 10 & $1.60 \times 10^{-3}$ & & & \\
Total & $1.60 \times 10^{-2}$ & 27 & & & & \\
\hline \multicolumn{7}{c}{} \\
& & & Anaerobic Treatment & & \\
\hline Rows & $8.59 \times 10^{-3}$ & 8 & $1.07 \times 10^{-3}$ & 278.6611 & 0 & 2.355081 \\
Columns & $3.03 \times 10^{-5}$ & 3 & $1.01 \times 10^{-5}$ & 2.622596 & 0.073802 & 3.008787 \\
Error & $9.24 \times 10^{-5}$ & 24 & $3.85 \times 10^{-6}$ & & & \\
Total & $8.71 \times 10^{-3}$ & 35 & & & & \\
\hline
\end{tabular}

\section{Experimental Work}

\subsection{Material and Methods}

Ferric chloride solution $\left(\mathrm{FeCl}_{3} \cdot 6 \mathrm{H}_{2} \mathrm{O}\right)$, sodium borohydride $\left(\mathrm{NaBH}_{4}, 98 \%\right)$ pure, and anhydrous ethanol $\left(\mathrm{C}_{2} \mathrm{H}_{5} \mathrm{OH}\right)$ were obtained from Merck KGaA, Mumbai, India. All the solutions were prepared with deionized water. All the chemicals used in the study were analytical grade and had not been purified further. A double distillation unit was used to make deionized water. Microporous membranes (Whatman cellulose nitrate filter paper $0.45 \mu \mathrm{m} \times 47 \mathrm{~mm}$ ) were used in vacuum filtration.

\subsection{Fabrication of $n Z V I$}

The nZVI nanoparticles were fabricated using the liquid-phase reduction method, which involved reducing the ferric chloride solution with $\mathrm{NaBH}_{4}$ as the reducing agent. A volume ratio of $4 / 1(v / v)$ ethanol/water mixture was vigorously reacted with sodium borohydride $(0.1 \mathrm{M})$ solution and anhydrous ferric chloride $(0.06 \mathrm{M})$. The borohydride solution was added dropwise into ferric chloride solution in a flask under constant stirring (300 rpm). After the initial drop of the borohydride solution, black particles appeared, and the remaining borohydride solution was added to accelerate the reduction reaction. The mixture was stirred for a few minutes before the nZVI particles were extracted from the liquid phase using vacuum filtration. The solid particles were washed twice with anhydrous ethanol to remove impurities. Finally, to avoid oxidation, fresh nZVI particles were stored in the drying chamber before use. 


\subsection{Characterization of $n Z V I$}

Several techniques were used to examine the structural, morphological, and physical properties of prepared nZVI particles. The UV-Vis spectrum was used to monitor the reduction in nZVI from pure $\mathrm{Fe}^{+3}$ ions by sampling aliquots of $\mathrm{Fe}^{\circ}$ nanoparticle solution and diluting the sample in distilled water. The peak wavelength between 200 and $800 \mathrm{~nm}$ was investigated using ultraviolet-visible spectroscopy (UV-Vis, Hitachi model-U3900, Tokyo, Japan). The surface chemistry and crystal phase compositions of the synthesized particles were determined using high-resolution X-ray diffraction (XRD, Rigaku Ultima IV, Tokyo, Japan) with an operating $2 \theta$ (degree) angle scanning range of $20^{\circ}$ to $80^{\circ}$ at a speed of $10^{\circ} \mathrm{min}^{-1}$. A high-resolution transmission electron microscope (HR-TEM, Model F30 S-Twin, Technai, Japan) and field emission scanning electron microscope (FE-SEM, Model No. SIGMA VP, Zeiss, Germany) were used to investigate the particles surface morphology and shape with an accelerating voltage of $200 \mathrm{kV}$ and $10-12.5 \mathrm{kV}$, respectively. The energydispersive X-ray spectroscopy (EDX) microanalysis equipped with SEM was used to analyze the composition and element distribution of prepared nanoparticles. Additionally, Dynamic Light Scattering was used to validate the particle size distribution profile (DLS, Model Zetasizer Nano ZS, Malvern, UK).

\subsection{Batch Experiments}

The wastewater sample was taken at the entrance to a domestic wastewater treatment plant in Okhla, New Delhi, India, which has a treatment capacity of 20 million gallons per day (MGD). The samples were collected from the inlet of WWTPs and stored at $4{ }^{\circ} \mathrm{C}$ in the laboratory after being pre-examined through a $2 \mathrm{~mm}$ mesh to remove larger particles. Table 5 summarizes the initial characteristics of various Physico-chemical parameters of raw wastewater. Batch studies were conducted to investigate the potential impact of nZVI nanoparticles on the wastewater treatment process, as well as the rates of COD solubilization, solid reduction, and phosphorous removal. To ensure the aerobic condition, the sample was continuously injected with oxygen for $30 \mathrm{~min}$, and nitrogen gas was used to purge dissolved oxygen (DO) in the same way for the anaerobic condition. In this study, $300 \mathrm{~mL}$ of raw sample was used, and experiments were carried out under aerobic and anaerobic conditions to examine the effect of different nZVI particle dosages $(100,200$, 300 , and $500 \mathrm{mg} / \mathrm{L}$ ). All experiments were vigorously shaken at $150 \mathrm{rpm}$ at $37^{\circ} \mathrm{C}$ using a reciprocating shaker (MaxQ-2508, Mumbai, India).

Table 5. Basic physico-chemical characteristics of raw domestic wastewater.

\begin{tabular}{cc}
\hline Parameter & Value \\
\hline $\mathrm{pH}$ & 8.75 \\
\hline Colour & Blue Black \\
\hline Temperature & $22^{\circ} \mathrm{C}$ \\
\hline Chemical oxygen demand (COD) & $680 \mathrm{mg} / \mathrm{L}$ \\
\hline Biological oxygen demand (BOD) & $163 \mathrm{mg} / \mathrm{L}$ \\
\hline Total suspended solids (TSS) & $332 \mathrm{mg} / \mathrm{L}$ \\
\hline Phosphorous (PO $\left.{ }^{3-}\right)$ & $13.86 \mathrm{mg} / \mathrm{L}$ \\
\hline Total Nitrogen (TN) & $53 \mathrm{mg} / \mathrm{L}$ \\
\hline Oil and Grease $(\mathrm{O}$ and G) & 12.4 \\
\hline $\mathrm{NH}_{4}$ & 60 \\
\hline
\end{tabular}

\subsection{Analytical Methods}

All the chemicals used in the experiment were analytical grade and had not been purified further. Standard Methods for the Examination of Water and Wastewater [53] were used to examine the samples. During the batch tests, $10 \mathrm{~mL}$ samples were extracted 
with a $20 \mathrm{~mL}$ syringe at specified predefined times of $0,20,40,80$, and $120 \mathrm{~min}$. The entire investigation was carried out in triplicate. Water samples were filtered using a $0.45 \mu \mathrm{m}$ disposable sterile syringe cellulose membrane filter (Merck KGaA, Mumbai, India). The standard method for water and wastewater examination was used to assess COD solubilization and solid reduction. The USEPA PhosVer (Ascorbic Acid) technique was used to determine phosphorus contents using a Hach spectrophotometer (DR 3900, Hach Company, Loveland, CO, USA). The concentration of DO was measured with a DO meter, and the $\mathrm{pH}$ was measured with a portable digital $\mathrm{pH}$ meter (Decibel Dynamics Ltd., Chandigarh, India).

\subsection{Statistical Analysis}

All analysis was carried out by using origin 2020 (Origin Lab, Northampton, MA, USA). Two-way analysis of variance (ANOVA), Pearson correlation coefficient, and Standard Deviation (SD) were used to examine the data.

\section{Conclusions}

The synthesis of $n Z V I$ was facilitated by infiltration of nZVI particles with a ferric chloride solution and reduction with sodium borohydride, as revealed by UV, XRD, SEM, EDS, and TEM studies. The results of this study showed that $\mathrm{nZVI}$ nanoparticles can successfully treat domestic wastewater with and without oxygen. The findings suggest that a high dose of nZVI particles added to wastewater improved COD, TSS, and Phosphorus removal efficiency throughout the degradation process. The nZVI can generate more ions under the anaerobic condition and play a crucial role in the removal of COD and phosphorous concentration during the treatment of domestic wastewater. The addition of 100 to $500 \mathrm{mg} / \mathrm{L}$ nZVI dose increased COD and TSS removal efficiency, with $400 \mathrm{mg} / \mathrm{L}$ nZVI providing the highest removal rate when compared to a higher dosage of catalyst concentrations. Furthermore, as compared to the aerobic condition, the anaerobic condition significantly increased the efficiency of phosphorus removal. The treated domestic wastewater can help fulfil the increasing demand for water supply. Overall, the ability to offer biological or chemical degradation of domestic wastewater will open plenty of new possibilities for better understanding and application of nZVI particles in wastewater treatment and resource recovery.

Author Contributions: A.A. Conceptualization, methodology, formal analysis, investigation, writing original draft preparation; V.U.S. resources, review and editing; M.K.A. review, editing and cosupervision; W.A.S. project administration, supervision; A.K. funding acquisition, review and editing; A.N.A.-R. funding acquisition, review and editing; M.A.H. funding acquisition, review and editing; M.P. funding acquisition, review and editing, All authors have read and agreed to the published version of the manuscript.

Funding: This research was funded by the Deanship of Scientific Research (DSR), King Abdulaziz University, Jeddah Saudi Arabia has funded this project, under grant no. (KEP-82-130-42).

Data Availability Statement: Not applicable.

Acknowledgments: The Deanship of Scientific Research (DSR) at King Abdulaziz University, Jeddah, Saudi Arabia has funded this project, under grant no. (KEP-82-130-42). The author, Afzal Ansari gratefully acknowledges the financial assistance in terms of "non-NET fellowship" by University Grant Commission (UGC), New Delhi. Further, the authors are also grateful to the Central Instrumentation Facility (CIF) and Centre for Nanoscience and Nanotechnology, Jamia Millia Islamia, New Delhi for providing the experimental facility.

Conflicts of Interest: The authors declare no conflict of interest. The funders had no role in the designs of the study; in the collection, analyses, or interpretation of data; in the writing of the manuscript, or in the decision to publish the results. 


\section{References}

1. Metcalf \& Eddy Inc.; Tchobanoglous, G.; Burton, F.L.; Stensel, H.D. Wastewater engineering: Treatment and resource recovery. In McGraw-Hill Series in Civil and Environmental Engineering, 5th ed.; McGraw-Hill Education: New York, NY, USA, 2014; ISBN 9781259010798.

2. Jain, K.; Patel, A.S.; Pardhi, V.P.; Flora, S.J.S. Nanotechnology in wastewater management: A new paradigm towards wastewater treatment. Molecules 2021, 26, 1797. [CrossRef] [PubMed]

3. Stefaniuk, M.; Oleszczuk, P.; Ok, Y.S. Review on nano zerovalent iron (nZVI): From synthesis to environmental applications. Chem. Eng. J. 2016, 287, 618-632. [CrossRef]

4. Zhu, Y.; Costa, M. Metals and molecular carcinogenesis. Carcinogenesis 2020, 41, 1161-1172. [CrossRef] [PubMed]

5. Ansari, A.; Siddiqui, V.U.; Akram, M.K.; Siddiqi, W.A.; Sajid, S. Removal of $\mathrm{Pb}$ (II) from industrial wastewater using of CuO/Alg nanocomposite. In Lecture Notes in Civil Engineering; Springer Nature: Singapore, 2020; pp. 167-175.

6. Pradeep, T.; Anshup; Bootharaju, M.S. Detection and extraction of pesticides from drinking water using nanotechnologies. In Nanotechnology Applications for Clean Water; Elsevier: Amsterdam, The Netherlands, 2014; pp. 241-270. ISBN 9781455731169.

7. Kumari, P.; Alam, M.; Siddiqi, W.A. Usage of nanoparticles as adsorbents for waste water treatment: An emerging trend. Sustain Mater. Technol. 2019, 22, e00128. [CrossRef]

8. Ariga, K.; Ishihara, S.; Abe, H.; Li, M.; Hill, J.P. Materials nanoarchitectonics for environmental remediation and sensing. J. Mater. Chem. 2012, 22, 2369-2377. [CrossRef]

9. Gautam, S.K.; Sharma, D.; Tripathi, J.K.; Ahirwar, S.; Singh, S.K. A study of the effectiveness of sewage treatment plants in Delhi region. Appl. Water Sci. 2013, 3, 57-65. [CrossRef]

10. Paul, E.; Camacho, P.; Sperandio, M.; Ginestet, P. Technical and economical evaluation of a thermal, and two oxidative techniques for the reduction of excess sludge production. Process Saf. Environ. Prot. 2006, 84, 247-252. [CrossRef]

11. Dadhore, H.; Kaur, C.; Shrivastava, S.; Choudhary, R. Synthesis and characterization of zero valent iron nanoparticles. Proc. Pollut. 2019, 6, 020021.

12. Sandhya, S.; Sarayu, K.; Swaminathan, K. Determination of kinetic constants of hybrid textile wastewater treatment system. Bioresour. Technol. 2008, 99, 5793-5797. [CrossRef]

13. Zhou, Y.; Wang, T.; Zhi, D.; Guo, B.; Zhou, Y.; Nie, J.; Huang, A.; Yang, Y.; Huang, H.; Luo, L. Applications of nanoscale zero-valent iron and its composites to the removal of antibiotics: A review. J. Mater. Sci. 2019, 54, 12171-12188. [CrossRef]

14. Abu Hasan, H.; Muhammad, M.H.; Ismail, N.I. A review of biological drinking water treatment technologies for contaminants removal from polluted water resources. J. Water Process Eng. 2020, 33, 101035. [CrossRef]

15. Khunjan, U.; Kasikamphaiboon, P. Green synthesis of kaolin-supported nanoscale zero-valent iron using ruellia tuberosa leaf extract for effective decolorization of azo dye reactive black 5. Arab. J. Sci. Eng. 2021, 46, 383-394. [CrossRef]

16. Raman, C.D.; Kanmani, S. Textile dye degradation using nano zero valent iron: A review. J. Environ. Manag. 2016, 177, 341-355. [CrossRef] [PubMed]

17. Lv, D.; Zhou, X.; Zhou, J.; Liu, Y.; Li, Y.; Yang, K.; Lou, Z.; Baig, S.A.; Wu, D.; Xu, X. Design and characterization of sulfide-modified nanoscale zerovalent iron for cadmium(II) removal from aqueous solutions. Appl. Surf. Sci. 2018, 442, 114-123. [CrossRef]

18. He, Z.; Mahmud, S.; Yang, Y.; Zhu, L.; Zhao, Y.; Zeng, Q.; Xiong, Z.; Zhao, S. Polyvinylidene fluoride membrane functionalized with zero valent iron for highly efficient degradation of organic contaminants. Sep. Purif. Technol. 2020, 250, 117266. [CrossRef]

19. Oller, I.; Malato, S.; Sánchez-Pérez, J.A. Combination of advanced oxidation processes and biological treatments for wastewater decontamination-A review. Sci. Total Environ. 2011, 409, 4141-4166. [CrossRef] [PubMed]

20. Bhatti, H.N.; Iram, Z.; Iqbal, M.; Nisar, J.; Khan, M.I. Facile synthesis of zero valent iron and photocatalytic application for the degradation of dyes. Mater. Res. Express 2020, 7, 015802. [CrossRef]

21. Adusei-Gyamfi, J.; Acha, V. Carriers for nano zerovalent iron (nZVI): Synthesis, application and efficiency. RSC Adv. 2016, 6 , 91025-91044. [CrossRef]

22. Wang, Q.; Sun, J.; Song, K.; Zhou, X.; Wei, W.; Wang, D.; Xie, G.-J.; Gong, Y.; Zhou, B. Combined zero valent iron and hydrogen peroxide conditioning significantly enhances the dewaterability of anaerobic digestate. J. Environ. Sci. 2018, 67, 378-386. [CrossRef]

23. Segura, Y.; Martínez, F.; Melero, J.A. Simple and efficient treatment of high-strength industrial waste water using commercial zero-valent iron. Chem. Pap. 2016, 70, 1059-1065. [CrossRef]

24. O'Carroll, D.; Sleep, B.; Krol, M.; Boparai, H.; Kocur, C. Nanoscale zero valent iron and bimetallic particles for contaminated site remediation. Adv. Water Resour. 2013, 51, 104-122. [CrossRef]

25. De, A.; De, A.K.; Panda, G.S.; Haldar, S. Synthesis of zero valent iron nanoparticle and its application as a dephenolization agent for coke oven plant wastewater situated in West Bengal: India. Environ. Prog. Sustain. Energy 2017, 36, 1700-1708. [CrossRef]

26. Thangadurai, T.D.; Manjubaashini, N.; Thomas, S.; Maria, H.J. Advanced nanostructured materials for environmental remediation. In Environmental Chemistry for a Sustainable World; Naushad, M., Rajendran, S., Gracia, F., Eds.; Springer International Publishing: Cham, Switzerland, 2019; Volume 25, ISBN 978-3-030-04476-3.

27. Al-Musawi, T.J.; Kamani, H.; Bazrafshan, E.; Panahi, A.H.; Silva, M.F.; Abi, G. Optimization the effects of physicochemical parameters on the degradation of cephalexin in sono-fenton reactor by using box-behnken response surface methodology. Catal. Lett. 2019, 149, 1186-1196. [CrossRef] 
28. Harada, T.; Yatagai, T.; Kawase, Y. Hydroxyl radical generation linked with iron dissolution and dissolved oxygen consumption in zero-valent iron wastewater treatment process. Chem. Eng. J. 2016, 303, 611-620. [CrossRef]

29. Liu, S.; Feng, H.; Tang, L.; Dong, H.; Wang, J.; Yu, J.; Feng, C.; Liu, Y.; Luo, T.; Ni, T. Removal of Sb(III) by sulfidated nanoscale zerovalent iron: The mechanism and impact of environmental conditions. Sci. Total Environ. 2020, 736, 139629. [CrossRef]

30. Liang, J.; Komarov, S.; Hayashi, N.; Kasai, E. Improvement in sonochemical degradation of 4-chlorophenol by combined use of Fenton-like reagents. Ultrason. Sonochem. 2007, 14, 201-207. [CrossRef]

31. Zhang, Y.; Feng, Y.; Yu, Q.; Xu, Z.; Quan, X. Enhanced high-solids anaerobic digestion of waste activated sludge by the addition of scrap iron. Bioresour. Technol. 2014, 159, 297-304. [CrossRef]

32. Bokare, A.D.; Choi, W. Review of iron-free Fenton-like systems for activating $\mathrm{H}_{2} \mathrm{O}_{2}$ in advanced oxidation processes. J. Hazard. Mater. 2014, 275, 121-135. [CrossRef]

33. Zhen, G.; Lu, X.; Li, Y.-Y.; Liu, Y.; Zhao, Y. Influence of zero valent scrap iron (ZVSI) supply on methane production from waste activated sludge. Chem. Eng. J. 2015, 263, 461-470. [CrossRef]

34. Zhou, X.; Wang, Q.; Jiang, G.; Liu, P.; Yuan, Z. A novel conditioning process for enhancing dewaterability of waste activated sludge by combination of zero-valent iron and persulfate. Bioresour. Technol. 2015, 185, 416-420. [CrossRef]

35. Bagbi, Y. Nanoscale zero-valent iron for aqueous lead removal. Adv. Mater. Proc. 2017, 2, 235-241. [CrossRef]

36. Sravanthi, K.; Ayodhya, D.; Yadgiri Swamy, P. Green synthesis, characterization of biomaterial-supported zero-valent iron nanoparticles for contaminated water treatment. J. Anal. Sci. Technol. 2018, 9, 3. [CrossRef]

37. Naran, E.; Toor, U.A.; Kim, D.-J. Effect of pretreatment and anaerobic co-digestion of food waste and waste activated sludge on stabilization and methane production. Int. Biodeterior. Biodegrad. 2016, 113, 17-21. [CrossRef]

38. Khoshnamvand, N.; Kord Mostafapour, F.; Mohammadi, A.; Faraji, M. Response surface methodology (RSM) modeling to improve removal of ciprofloxacin from aqueous solutions in photocatalytic process using copper oxide nanoparticles (CuO/UV) $A M B$ Express 2018, 8, 48. [CrossRef] [PubMed]

39. Seid-Mohammadi, A.; Ghorbanian, Z.; Asgari, G.; Dargahi, A. Photocatalytic degradation of metronidazole (MNZ) antibiotic in aqueous media using copper oxide nanoparticles activated by $\mathrm{H}_{2} \mathrm{O}_{2} / \mathrm{UV}$ process: Biodegradability and kinetic studies. Desalin. Water Treat. 2020, 193, 369-380. [CrossRef]

40. Amen, T.W.M.; Eljamal, O.; Khalil, A.M.E.; Matsunaga, N. Wastewater degradation by iron/copper nanoparticles and the microorganism growth rate. J. Environ. Sci. 2018, 74, 19-31. [CrossRef] [PubMed]

41. Pillai, P.; Kakadiya, N.; Timaniya, Z.; Dharaskar, S.; Sillanpaa, M. Removal of arsenic using iron oxide amended with rice husk nanoparticles from aqueous solution. Mater. Today Proc. 2020, 28, 830-835. [CrossRef]

42. Zhou, X.; Wang, Q.; Jiang, G.; Zhang, X.; Yuan, Z. Improving dewaterability of waste activated sludge by combined conditioning with zero-valent iron and hydrogen peroxide. Bioresour. Technol. 2014, 174, 103-107. [CrossRef]

43. Martins, R.C.; Lopes, D.V.; Quina, M.J.; Quinta-Ferreira, R.M. Treatment improvement of urban landfill leachates by Fenton-like process using ZVI. Chem. Eng. J. 2012, 192, 219-225. [CrossRef]

44. Şahinkaya, S.; Kalıpcı, E.; Aras, S. Disintegration of waste activated sludge by different applications of Fenton process. Process Saf. Environ. Prot. 2015, 93, 274-281. [CrossRef]

45. Sheng, G.-P.; Yu, H.-Q.; Li, X.-Y. Extracellular polymeric substances (EPS) of microbial aggregates in biological wastewater treatment systems: A review. Biotechnol. Adv. 2010, 28, 882-894. [CrossRef]

46. Segura, Y.; Martínez, F.; Melero, J.A.; Fierro, J.L.G. Zero valent iron (ZVI) mediated Fenton degradation of industrial wastewater: Treatment performance and characterization of final composites. Chem. Eng. J. 2015, 269, 298-305. [CrossRef]

47. Kim, T.-H.; Lee, S.-R.; Nam, Y.-K.; Yang, J.; Park, C.; Lee, M. Disintegration of excess activated sludge by hydrogen peroxide oxidation. Desalination 2009, 246, 275-284. [CrossRef]

48. Pham, T.T.H.; Brar, S.K.; Tyagi, R.D.; Surampalli, R.Y. Optimization of Fenton oxidation pre-treatment for B. thuringiensis-Based production of value added products from wastewater sludge. J. Environ. Manag. 2010, 91, 1657-1664. [CrossRef]

49. Eljamal, R.; Eljamal, O.; Khalil, A.M.E.; Saha, B.B.; Matsunaga, N. Improvement of the chemical synthesis efficiency of nano-scale zero-valent iron particles. J. Environ. Chem. Eng. 2018, 6, 4727-4735. [CrossRef]

50. Wu, B.; Wan, J.; Zhang, Y.; Pan, B.; Lo, I.M.C. Selective phosphate removal from water and wastewater using sorption: Process fundamentals and removal mechanisms. Environ. Sci. Technol. 2020, 54, 50-66. [CrossRef]

51. Liu, A.; Liu, J.; Zhang, W. Transformation and composition evolution of nanoscale zero valent iron (nZVI) synthesized by borohydride reduction in static water. Chemosphere 2015, 119, 1068-1074. [CrossRef]

52. Lv, X.; Hu, Y.; Tang, J.; Sheng, T.; Jiang, G.; Xu, X. Effects of co-existing ions and natural organic matter on removal of chromium (VI) from aqueous solution by nanoscale zero valent iron (nZVI)-Fe $\mathrm{O}_{4} \mathrm{O}_{4}$ nanocomposites. Chem. Eng. J. 2013, 218, 55-64. [CrossRef]

53. Baird, R.; Rice, E.W.; Eaton, A.D.; Bridgewater, L.; Water Environment Federation. Standard Methods for the Examination of Water and Wastewater, 23rd ed.; American Public Health Association: Alexandria, VA, USA, 2017; ISBN 9780875532875. 